\title{
Analyses of the First 410 days of COVID-19 Trend and Mortality in Africa: Interpretation, Implications and Recommendations
}

Adeloye Adeniji ( $\square$ adenijitemitope7@gmail.com )

Stellenbosch University

\section{Temidayo S Omolaoye}

Mohammed Bin Rashid University of Medicine and Health Sciences

\section{Stefan S Plessis}

Mohammed Bin Rashid University of Medicine and Health Sciences

\section{Kazeem Okosun \\ 100BC Online LLC}

Colette Gunst

Stellenbosch University

\section{Research Article}

Keywords: Covid-19, SARS-Cov-2, Africa continent, Mortality, Morbidity

Posted Date: November 23rd, 2021

DOl: https://doi.org/10.21203/rs.3.rs-1077483/v1

License: (c) (i) This work is licensed under a Creative Commons Attribution 4.0 International License. Read Full License 


\section{Abstract \\ Background}

Severe acute respiratory syndrome coronavirus 2 (SARS-CoV-2), also referred to as COVID-19 initially spread from Europe to Africa. On the 14th of February 2020, the African continent reported its first COVID19 case in Egypt. Other African countries such as Algeria, Nigeria, and Senegal subsequently reported their first cases a few weeks later. The spread and the resulting mortality from COVID-19 has been disproportionate over the African continent.

\section{Aim}

In this study, we look into the trend and progression of COVID-19, in terms of morbidity (number of confirmed cases) and mortality, over a specified period within a designated geographic area. Review of this data enabled the identification of unique characteristics of this pandemic in the five designated regions of the African continent.

\section{Method}

We analyzed the mortality that resulted from COVID-19 infection and the trend of spread during the time period (3 January 2020 -31 March 2021). We further use the data to explore and forecast COVID-19 trends in these African countries using time series analysis and centre moving averages (CMA) in Microsoft Excel statistical package.

\section{Results}

In Northern Africa, Egypt had the highest number of cumulative cases and deaths (cases: 201432 and deaths: 11956) by the 31st of March 2021. For the other four regions of the African continent Nigeria (cases: 162762 and deaths: 2056) in West Africa; Ethiopia (cases: 204521 and deaths: 2841) in the Eastern region; Cameroon (cases: 47669) and deaths: 721) in Central Africa. And South Africa (cases: 1546735 and deaths: 52788) in the Southern region reported the highest cumulative cases and deaths at the same point in time. Based on these results, comparative forecasts were made in terms of the expected period and fatality of subsequent waves of COVID 19.

\section{Conclusion}

While there should be caution in interpreting data from the African continent, the reported findings could lend itself to productive scientific inquiry and interpretations. Africa need to consider various implementable approaches to managing this pandemic without creating another epidemic due to neglect 
of other components of her health priorities. Implications were inferred and recommendations were made in the interest of the continent and global community of Nations.

\section{Introduction}

Disease outbreak occurrences are not new to Africa. In the past three decades, the commonly reported epidemic outbreaks in Africa include Diarrhoea diseases (cholera/ dysentery), malaria, cyclic meningococcal meningitis and hemorrhagic fevers (e.g. Ebola, Rift Valley fever, Crimean-Congo fever and yellow fever) ${ }^{1,2}$.While Human immunodeficiency virus (HIV) infection has been the dominant epidemic in Africa since discovery, tuberculosis(TB) is a global health challenge with enormous impact on the continent .

Communicable disease outbreaks still cause millions of deaths throughout Sub-Saharan Africa each year, even though, most of the diseases causing epidemics in the continent have nearly been eradicated or brought under control in other parts of the world ${ }^{2}$. Severe acute respiratory syndrome coronavirus 2 (SARS-COV-2), also called COVID-19, is the latest health challenge to hit Africa and it might be too early to quantify the extent of damage this pandemic will have on the already disadvantaged continent.

In Africa, the dominant epidemics in the region are vector transmitted, hygiene or lifestyle-related. For this reason, researchers have devoted resources and studies into understanding the character of epidemic outbreaks in Africa.

Malaria, for instance, is a very big health burden in Africa. Mosquito vectors of malaria can transmit several pathogens, including arboviruses, protozoans and filariae that cause infectious diseases of significant public health concern ${ }^{3}$. The comprehensive list of mosquito species currently recorded includes 106 species (28 species of the Anophelinae and 78 species of the Culicinae) ${ }^{3}$. While the World Health Organisation (WHO) is directing a lot of resources towards vector control worldwide ${ }^{4}$, globalisation and international travels have been identified as perennial factors that will continue to perpetuate pathogen dispersion beyond the shores of Africa ${ }^{5}$.

HIV infection on the other hand also continues to be another major global health threat, particularly in Africa which accounts for $67 \%$ of the world's infections ${ }^{6}$. This disease, which was first identified and documented among the young gay men and people who inject drugs in America in 1981, was later traced to have originated from the Democratic Republic of Congo in the 1920s via the bush meat trading ${ }^{7}$. The relationships and pathogenesis of Simian immunodeficiency virus of Apes and HIV put some level of validity on this assertion ${ }^{7}$. HIV has contributed significantly to the burden of disease (BOD) in Africa and the socioeconomic impact on the underdeveloped continent is remarkable.

Development in genetic sequencing has paid off in deep understanding of $\mathrm{HIV}^{8,9}$. This diversification of genomes, sequences, groups, and strains create a big challenge in vaccine development. The trends and continental effect of HIV in Africa are medically, socially, and economically remarkable. 
The emergence of HIV lead to retrogression in the concerted global efforts to exterminate TB due to the cumulative effects of association in pathogenesis of the two diseases. Geographically, most people who developed TB in 2019 were in the WHO regions of South-East Asia (44\%), Africa (25\%) and the Western Pacific (18\%), with smaller percentages in the Eastern Mediterranean (8.2\%), the Americas $(2.9 \%)$ and Europe $(2.5 \%)^{10}$. Eight countries accounted for two thirds of the global total: India (26\%), Indonesia (8.5\%), China (8.4\%), the Philippines (6.0\%), Pakistan (5.7\%), Nigeria (4.4\%), Bangladesh (3.6\%) and South Africa $(3.6 \%){ }^{10}$. Unfortunately, the decades' gains achieved from different TB programs may be reversed by the present COVID-19 pandemic.

In addition, Diarrhoea/ diseases are the third leading cause of disease and death in children younger than 5 years of age in Africa and were responsible for an estimated 30 million cases of severe diarrhoea $(95 \%$ credible interval, 27 million to 33 million) and 330,000 deaths (95\% credible interval, 270,000 to 380,000 ) in $2015^{11}$.. Underlying HIV-1 infection, malaria, or severe malnutrition might render African children more susceptible to fatality following complicated and uncomplicated diarrhoea diseases.

For example, the Global BOD study in 2016 showed that the highest rate of diarrhoea mortality among children younger than 5 years occurred in Chad (499 deaths [345-686] per 100 000), the Central African Republic (384.2 deaths [237-596] per 100000 ), and Niger (376 deaths [234-559] per 100000$)^{12}$. This report raised an alert on the unusual mortality of the elderlies from diarrhoea and diarrhoea mortality among adults older than 70 years was found to be highest in Kenya (1877 deaths [1184-3029] per 100 000), Central African Republic (1282 deaths [680-2112] per 100 000), and India (1013 deaths [667-1578] per 100000$)^{12}$.

The Global Enteric Multi-centre Study (GEMS) contributed to deep understanding of major pathogens associated with diarrhoeal disease ${ }^{13}$, however, there are lots of social and environmental factors which must be addressed in Africa to achieve substantial clinical outcomes.

On the 31st December 2019, China reported incidence of cases of widespread pneumonia of unknown aetiology in the city of Wuhan ${ }^{14}$, this was initially thought to be a resurgence of an earlier epidemic witnessed in the year 2002 in the same region ${ }^{14}$. It was later confirmed that the aetiological agent of this disease was different from the previous ones, even though, it belonged to the same family with SARS-CoV and the Middle East respiratory syndrome (MERS) viruses ${ }^{15-17}$.

As a novel virus, its uniqueness was initially unknown, but advances in sequencing technology paid off in its early identification. The analyses show that the SARS-CoV-2 genomes sequenced are located mainly in three clades, in addition to others, S clade (541 genomes), G clade (931), V clade (208), and other additional clades (548) ${ }^{18}$; however, there were initial uncertainties about the mode of transmission and non-therapeutic means of preventing the spread. It was later confirmed that the virus spread by droplets and restriction of movement would be crucial to curtail the spread.

The continent of Africa confirmed its first case of COVID-19 in Egypt on the 14th of February 2020, and from sub-Saharan Africa, the first case was reported in Nigeria on the 27th of February 2020, through an 
Italian traveller who flew to Nigeria from Italy on the 25th of February, $2020^{19}$. The virus spread through all the 5 regions in Africa by the end of March 2020.

As of March 29th, 2021, over 130.5 million people were infected with COVID-19 globally, with a $3.25 \%$ weekly increase. At the same point in time there were 2,843,127 confirmed COVID-19 related deaths with a $2.6 \%$ weekly increase in deaths reported globally 20 .

Similar to most epidemics that have riddled Africa, costing millions of lives with accompanying long term social and economic impact, COVID-19 is not expected to be different. The current study, therefore, aimed to analyse the trend and progression of COVID-19, in terms of morbidity (number of confirmed cases) and mortality, during the first 410 days of the pandemic, within a designated geographic area. Review of this data enabled the identification of unique characteristics of this pandemic in the five designated regions of the African continent.

\section{Material And Method}

\section{Search method}

To investigate the trend of occurrence and the rate of mortality during the first 410 days of COVID-19 infection in Africa (February 14, 2020 - March 31, 2021), we retrieved COVID-19 data sheets from the World Health Organization (WHO) COVID-19 database ${ }^{20}$, and categorized countries and regions with their respective parameters. The parameters of interest include new cases, cumulative cases, new deaths, and cumulative deaths. Then, the data for African countries were extracted from the global data sheet and analysed. For proper comprehension of the results, African countries were divided into five regions, based on the World Atlas ${ }^{21}$ (Table 1).

\section{Statistical Analysis}

In this study, we examine and analyze the daily COVID-19 data from February 2020 to March 2021 to study the transmission trends and pattern of COVID-19 in five African countries. We further use the data to explore and forecast COVID-19 trends in these African countries using time series analysis and centre moving averages (CMA) in Microsoft Excel statistical package. The forecast produces a reasonable fit with the observed data and in particular, it captures all the first and second waves of COVID-19 spikes in 2020. Noting that each of the COVID-19 waves are of six months intervals, we used CMA(6) to mimic the trends and forecast the future COVID-19 waves. It is worth noting that the projections did not consider any intervention measures that are currently being implemented to curtail COVID-19 in the respective countries.

\section{Results}

Following data extraction and analysis, the country with the highest number of cumulative cases in each African region was selected; that is, one country per each of the five regions. Findings from these five countries are explained in the results section of the current study. Illustrated in Table 2 is the list of 
countries with the highest number of infection cases and deaths (Table 2).

In Northern Africa, Egypt had the highest number of cumulative cases and deaths (cases: 201432 and deaths: 11956) by the 31st of March 2021. Nigeria had the highest numbers (cases: 162762 and deaaths: 2056) in West Africa, Ethiopia (cases: 204521 and deaths: 2841) in the Eastern region and Cameroon was the country with the highest number of cumulative cases (47669) and deaths (721) in Central Africa. South Africa on the other hand, represent the country with the highest number of cumulative cases and deaths (cases: 1546735 and deaths: 52788), both in the Southern region of Africa and the whole of the African continent (Table 2).

The graphs showing the new cases of infection and new mortality trends in each of the selected five African countries are depicted in Figures 1-5. Interestingly, until the 31st March 2021, Saint Helena, an island in the South Atlantic forming part of the West African region did not report any incidence of COVID19 infection, while the archipelago island nation of Seychelles off the East coast of Africa recorded zero deaths.

North Africa - Egypt

The graph for the new cases in Egypt (Figure 1) shows a steady increase from January 2020 to June 2020 before gradually declining between June and August 2020. The rise in new cases peaked in June 2020. In September 2020, a steady increase in the number of cases was again noticed and peaked in January 2021. These show a pattern or trend of seasonality. The number of new deaths shows a similar trend and pattern. After the initial gradual increase in new death, the numbers increased sharply beginning from April 2020 and peaked in June 2020. Thereafter, a decline was observed in July 2020, which gradually increased again from November 2020 and peaked in January 2021. The early rise in new deaths was expected. The rise in new deaths was because of possible insufficient information regarding the handling of COVID-19 at that time. However, this number of new deaths started dropping from July (the sixth months after the first case was recorded) as well as a decrease in new infection cases. This might have resulted from better insight into COVID-19 transmission dynamics and the provision of more medical facilities and equipment to curtail the fatality of the disease (Figure $1 \mathrm{~A}$ ).

Represented in Figure 1B and C are the COVID-19 forecast for Egypt for the next 11 months. The projections did not put into consideration any intervention measures that are currently being implemented to curtail COVID-19 in Egypt. By projections, within the next 11 months, Egypt should expect 2 waves of COVID-19 (Figure 1B, C). The 1st forecasted wave will start from April 2021, and will peak at 70,743 new cases in the month of June 2021. Thereafter a 2nd wave is forecasted to begin around October 2021, which will peak at 77,714 of new cases in December 2021. Similarly, the new deaths are anticipated to also follow suite from the month of April 2021 reaching a peak in July 2021 with 4313 new deaths to be expected. The 2nd forecasted wave of COVID-19 related new deaths is likely to start during October 2021 and will peak in January 2022 with 4783 new deaths.

West Africa - Nigeria

The new cases graph for Nigeria (Figure 2) shows a steady increase from February to July 2020 before gradually declining between August and October 2020. The rise in new cases first peaked in July. In 
November 2020, a steady increase in the number of cases was again observed and peaked again in January 2021, depicting patterns or trends of seasonality. Also, the number of new deaths shows a similar trend and pattern to new infection cases. There was an initial gradual increase in new deaths, the numbers increased sharply in April 2020 and peaked in July 2020. A decline was observed immediately, which gradually decreased till October 2020. The rise in new deaths was more than likely due to a lack of expertise and medical infrastructure to handle the COVID-19 at that time. However, the number of new infection cases as well as new deaths started dropping in July a. However, by the start of the second half of 2020 better insight into COVID-19 transmission dynamics led to curtailing the fatality of the disease. Figure 2B and $\mathrm{C}$ show the CoVID-19 projection for Nigeria for the next 11 months. For Nigeria, the data is projecting that within the next 11 months, the country should expect 2 waves of COVID-19 cases and deaths. The 1st forecasted wave is antipcipated to start from April 2021, which will peak in the month of July 2021, while the 2nd wave is likely to start in November 2021, reaching a peaking in January 2022. The forecasted number of new cases during these two waves are estimated to peak at 115,690 and 131,131 respectively. Similarly, the projected number of new deaths is expected to follow the same trend as the number of new infection cases for the 1st wave starting from the month of May 2021 to potentially peak in July 2021 with an expected 632 new deaths. The 2nd COVID-19 related new deaths wave is likely to start in November 2021 and will peak in January 2022 at 672 new deaths.

\section{East Africa - Ethiopia}

Ethiopia's new cases graph shows a steady increase from March to July 2020, with a sharp increase from July to August 2020 (Figure 3). The new cases gradually declined from August till December 2020. The rise in new cases first peaked in August 2020. In January 2021, a steady increase in the number of cases was again observed, this signalled seasonality patterns or trends possibilities. Also, the number of new deaths shows a similar trend and pattern to the new infection cases trend. There was an initial gradual increase in new deaths, the numbers increased sharply from July 2020 and peaked in August 2020. A decline was observed immediately after which it gradually decreased till the end of the year. Available data shows that Ethiopia is still in their 1 st wave and the second wave just started in January 2021. Since the 2nd wave is still ongoing, the completed data could not be extracted for projection purposes and thus no forecasts were made for this country.

\section{Central Africa - Cameroon}

Cameroon's new cases graph shows a steady increase from March 2020 to June before decreasing gradually between June and December 2020 (Figure 4). The country's new infection cases rose and had a 1st peak in June 2020. In February 2021, a sharp increase in the number of cases was again observed. Also, following a similar pattern, the number of new deaths shows an initial gradual increase, the numbers increased beginning from March 2020 and peaked in June 2020. Thereafter, a gradual decrease was observed untill the end of the year.

Southern Africa - South Africa

South Africa's new cases graph shows a steady increase from March to May 2020 and then sharply increased from May to July 2020 (Figure 5). The new cases declined between July and September 2020. 
The peak month for new cases was July 2020. In November 2020, a steady increase in the number of cases was again observed and peaked in January 2021, depicting patterns or trends of seasonality. Also, the number of new deaths shows similar trends and patterns. Innitially there was a gradual increase in new deaths; the numbers increased substantially from May 2020 and peaked in August 2020. Thereafter an immediate decline was observed followed by a gradual decrease till the end of November 2020. The second wave of new infections and deaths started in November and lasted until February 2021.

Represented in figure 5B and C are the COVID-19 projection for South Africa for the next 11 months. It should be noted that these projections did not put into consideration any intervention measures (such as vaccine) that are currently being implemented to curtail COVID-19 in South Africa. By projections, within the next 11 months, South Africa should expect another 2 waves of COVID-19. The 1st wave will start during May 2021, which is expected to peak by July 2021, and the 2 nd wave is presumed to start during November 2021 and will peak by January 2022, with the forecasted number of new cases to peak at $1,181,838$ and 1,332,719 respectively. Similarly, the new deaths are expected to follow the same pattern, starting from May and peaking in July 2021 at 42,182 expected deaths. The 2nd COVID-19 related new death wave is estimated to start in November 2021 and is anticipated to peak at 48,168 new deaths in January 2022.

Implications of the findings

Implementing effective public health intervention to curb the spread of COVID-19 in Africa is difficult. Poverty is a strong driver of the factors responsible for this. Overpopulation, migration, immigration, and demographic characteristics of Africa all form the fertile ground for the spread of infectious diseases and specifically COVID-19 22.

Similarly, the treatment options for infectious diseases in Africa is not easily accessible due to perennial factors enriched by the poor socioeconomic status of the African countries 23. War, famine, terrorism, and political unrest may affect vaccine distribution and implementation in some of the African countries. Globally, the demands of the pandemic have exposed the weaknesses of the existing health systems. These weaknesses are reflected in the inequalities in the health resources and administration across the African countries and there are growing concerns about the indirect impacts of the COVID-19 pandemic on the general health of Africans. The mechanisms employed to curtail the spread actually subjugate the atrisk population to potential hazards. Physical inactivity has been related to every described risk factor for metabolic syndrome, such asdyslipidemia, hypertension, hyperglycemia, visceral obesity, and prothrombotic and proinflammatory events 24 . People with chronic lifestyle diseases are most likely to develop complications of uncontrolled medical conditions due to restrictions and reduced access to health care facilities. Tuberculosis is most likely to spread rapidly locally due to some restraint on free access to healthcare facilities compounded by lack of access to decent housing and overpopulation. HIV prevalence is expected to increase, and virological suppression rate may be reduced among the patients on antiretroviral (ARV) agents.

The long-term health implications of COVID-19 does not spare the children. Diversion of the insufficient resources to COVID-19 management will soon start to affect preventative programs like immunizations and school health. Care of children with diarrhoea, malaria, tuberculosis and malnutrition might also suffer retribution due to priority shift of already weakened health system. The children from marginalized 
communities are particularly susceptible to the infection and may suffer from extended ill-consequences of this pandemic, such as child labour, child trafficking, child marriage, sexual exploitation and death 25. The dynamics of spread, resulting mortalities and expansive time to cure or prevention of COVID-19 are very harsh reminders of the inequality in global health. The same parameters also echo the need for transversal collaboration between high-income countries and disadvantaged economies to end the spate of COVID-19 pandemic.

\section{Conclusion And Recommendation}

The reality of COVID-19 is beyond a travesty. SARS-COV-2 infection is a zoonotic infection that has crossed the intermediate host to establish itself in the human host ${ }^{26}$. Its enormous impact on the world health and economy is highly concerning. The analyses above show forecasted periodic infections with accompanying mortality of unending trend in the absence of appropriate interventions. This novel virus deserves novel strategies to control and manage its spread. The novel strategies should be systematically developed to reduce morbidity and mortality in the disadvantaged continents. While options in terms of choices of vaccine is limited to factors of efficacy and safety informed by emerging viral molecular strains and variances, strong scientific decision in vaccine selection should be encouraged. The following are recommended to reduce the impact of COVID-19 in Africa.

1. The preventative measures should be implemented on a continuous basis until the vaccine development and the length of efficacy is scientifically confirmed.

2. African union backed policy is needed to enforce an increase in the health budgets of all African states for the next five years. A modest scale-up in the health workforce and resources mobilization will be very urgent for Africa to survive this pandemic without grave effects on the other known African related diseases and ill health.

3. Inter-African state collaboration and advocacy should be encouraged. All trans-Atlantic relationships and collaborations should have health assistance embedded in their modus operandi for the foreseeable future.

4. People in Africa should be encouraged or motivated to generally accept vaccination.

5. Manufacturing adequate vaccine doses for the majority of the world's population, affordable pricing and appropriate vaccine financing mechanisms, and public sector support would need to put the peculiarity of the African continent into careful consideration

6. A single dose vaccine without a follow-up booster will benefit African countries better due to limited resources for vaccine program implementation.

\section{Declarations}

\section{Acknowledgement}

We use this project to acknowledge all the frontline healthcare workers in Africa (Doctors, Nurses, Phamacists, Laboratory scientists, Researchers etc. ) who lost their lives to Covid -19 in the course of their 
professional duties. TSO also acknowledges Al jalila Fundation for the generous donation towards the completion of her Postdoctoral Fellowship.

\section{Competing interest}

The authors declare that no conflict of interests exist.

\section{Authors' Contributions}

All the authors worked together to make this project a reality . AAA conceptualised, wrote, reviewed and administered the Manuscript; TSO did the data curation,validation, writing and referencing; SDP reviewed, edited and validated the manusript ; KO did the formal data analysis, wrote, and edited the manusript and CG reviewed, edited and validated the manuscript. All the authors approved the final draft of the manuscript

\section{Ethical considerations}

As this study involves no human or animal study participants, no ethic considerations or approval is required.

\section{Funding information}

This study received no specific grant from any funding agency in the public, commercial or not-for-profit sectors. However this publication was indirectly supported by Al Jalila Foundation through their funding of the Postdoctoral fellowship of TSO.

\section{Data Availability.}

This project used the COVID-19 data sheets from the World Health Organization (WHO) COVID-19 database. Available from: https://www.who.int/health-topic/coronavirus\#tab=tab_1. The generated data and figures are freely available from the corresponding author.

\section{Disclaimer}


The views and opinions expressed in this article are those of the authors and do not necessarily reflect the official policy or position of any affliated agency of the authors.

\section{References}

1. Shears P. Emerging and reemerging infections in Africa: The need for improved laboratory services and disease surveillance. Microbes Infect 2000;2:489-95.

2. Kebede S, Duales S, Yokouide A, Alemu W. Trends of major disease outbreaks in the African region, 2003-2007. East Afr J Public Health 2010;7(1):20-9.

3. Tandina F, Doumbo O, Yaro AS, Traoré SF, Parola P, Robert V. Mosquitoes (Diptera: Culicidae) and mosquito-borne diseases in Mali, West Africa. Parasites and Vectors. 2018;11(1).

4. Smith Gueye C, Newby G, Gosling RD, et al. Strategies and approaches to vector control in nine malaria-eliminating countries: A cross-case study analysis. Malar J 2016;15(1).

5. Semenza JC, Suk JE. Vector-borne diseases and climate change: A European perspective. FEMS Microbiol. Lett. 2018;365(2).

6. Boyda DC, Holzman SB, Berman A, Kathyrn Grabowski M, Chang LW. Geographic information systems, spatial analysis, and HIV in Africa: A scoping review. PLoS One 2019;14(5).

7. Peeters $M$, Jung M, Ayouba A. The origin and molecular epidemiology of HIV. Expert Rev. Anti. Infect. Ther. 2013;11(9).

8. McCutchan FE. Global epidemiology of HIV. J. Med. Virol. 2006;78(SUPPL. 1).

9. Visseaux B, Damond F, Matheron S, Descamps D, Charpentier C. Hiv-2 molecular epidemiology. Infect Genet Evol 2016;46.

10. World Health Organization. Global tuberculosis report 2020. ISBN 978-92-4-001313-1 (electronic version). 2020;

11. Reiner RC, Graetz N, Casey DC, et al. Variation in Childhood Diarrheal Morbidity and Mortality in Africa, 2000-2015. N Engl J Med 2018;379(12).

12. Troeger $\mathrm{C}$, Blacker BF, Khalil IA, et al. Estimates of the global, regional, and national morbidity, mortality, and aetiologies of diarrhoea in 195 countries: a systematic analysis for the Global Burden of Disease Study 2016. Lancet Infect Dis 2018;18(11).

13. Levine MM, Nasrin D, Acácio S, et al. Diarrhoeal disease and subsequent risk of death in infants and children residing in low-income and middle-income countries: analysis of the GEMS case-control study and 12-month GEMS-1A follow-on study. Lancet Glob Heal 2020;8(2).

14. Chen Y, Liu Q, Guo D. Emerging coronaviruses: Genome structure, replication, and pathogenesis. J. Med. Virol. 2020;92(4).

15. Peeri NC, Shrestha N, Siddikur Rahman M, et al. The SARS, MERS and novel coronavirus (COVID-19) epidemics, the newest and biggest global health threats: what lessons have we learned? Int. J. Epidemiol. 2021;49(3). 
16. Ramadan N, Shaib H. Middle east respiratory syndrome coronavirus (MERS-COV): A review. GERMS. 2019;9(1).

17. Vijayanand P, Wilkins E, Woodhead M. Severe acute respiratory syndrome (SARS): A review. Clin. Med. J. R. Coll. Physicians London. 2004;4(2).

18. Rodríguez-Morales AJ, Balbin-Ramon GJ, Rabaan AA, et al. Genomic epidemiology and its importance in the study of the covid-19 pandemic. Infez. Med. 2020;28(2).

19. Lone SA, Ahmad A. COVID-19 pandemic-an African perspective. Emerg. Microbes Infect. 2020;9(1).

20. World Health Organization. SARS-CoV-2 (COVID-19) Global Datasheet [Internet]. 2021 [cited $2021 \mathrm{Mar}$ 31];Available from: https://www.who.int/health-topics/coronavirus\#tab=tab_1

21. Atlas W. Regions of Africa Continent [Internet]. 2021 [cited 2021 Apr 15];Available from: https://www.worldatlas.com/webimage/countrys/af.htm

22. Li YT, Ren GH, Liang YS, et al. Global burden and challenges of parasitic diseases in Africa. Chinese $J$ Schistosomiasis Control 2018;30(2).

23. Arora NK, Das MK. COVID-19 vaccine development and the way forward. Indian J Public Health 2020;64.

24. Martinez-Ferran M, de la Guía-Galipienso F, Sanchis-Gomar F, Pareja-Galeano H. Metabolic impacts of confinement during the COVID-19 pandemic due to modified diet and physical activity habits.

Nutrients. 2020;12(6).

25. Ghosh R, Dubey MJ, Chatterjee S, Dubey S. Impact of COVID-19 on children: Special focus on the psychosocial aspect. Minerva Pediatr. 2020;72(3).

26. MacKenzie JS, Smith DW. COVID-19: A novel zoonotic disease caused by a coronavirus from China: What we know and what we don't. Microbiol Aust 2020;41(1).

\section{Tables}

Table 1: List of African countries classified into regions following the World Atlas ${ }^{21}$ 


\begin{tabular}{|c|c|c|c|c|}
\hline Northern Africa & $\begin{array}{l}\text { West } \\
\text { Africa }\end{array}$ & East Africa & Central Africa & $\begin{array}{c}\text { Southern } \\
\text { Africa }\end{array}$ \\
\hline Algeria & Benin & Burundi & Angola & Botswana \\
\hline Canary Island & $\begin{array}{c}\text { Burkina } \\
\text { Faso }\end{array}$ & Comoros & Cameroon & Swaziland \\
\hline Ceuta & $\begin{array}{l}\text { Cape } \\
\text { Verde }\end{array}$ & Djibouti & $\begin{array}{c}\text { Central African } \\
\text { Republic }\end{array}$ & Lesotho \\
\hline Egypt & $\begin{array}{l}\text { Ivory } \\
\text { Coast }\end{array}$ & Eritrea & Chad & Namibia \\
\hline Libya & Gambia & Ethiopia & $\begin{array}{c}\text { Democratic Republic } \\
\text { of Congo }\end{array}$ & $\begin{array}{l}\text { South } \\
\text { Africa }\end{array}$ \\
\hline Madeira & Ghana & $\begin{array}{c}\text { French Southern } \\
\text { Territories }\end{array}$ & Republic of Congo & Zimbabwe \\
\hline Melilla & Guinea & Kenya & Equatorial Guinea & Malawi \\
\hline Morocco & $\begin{array}{l}\text { Guinea- } \\
\text { Bissau }\end{array}$ & Madagascar & Gabon & Zambia \\
\hline $\begin{array}{c}\text { Sahara Arab } \\
\text { Democratic Republic }\end{array}$ & Liberia & Malawi & $\begin{array}{l}\text { Sao Tome and } \\
\text { Principe }\end{array}$ & \\
\hline Sudan & Mali & Mauritius & & \\
\hline \multirow[t]{10}{*}{ Tunisia } & Mauritania & Mayotte & & \\
\hline & Niger & Mozambique & & \\
\hline & Nigeria & Reunion & & \\
\hline & $\begin{array}{l}\text { Saint } \\
\text { Helena }\end{array}$ & Rwanda & & \\
\hline & Senegal & Seychelles & & \\
\hline & $\begin{array}{l}\text { Sierra } \\
\text { Leone }\end{array}$ & Somalia & & \\
\hline & Togo & Somali land & & \\
\hline & & South Sudan & & \\
\hline & & Tanzania & & \\
\hline & & Uganda & & \\
\hline & & & & \\
\hline
\end{tabular}




\begin{tabular}{|l|l|l|l|} 
& Zambia & & \\
\hline
\end{tabular}

Table 2: List of countries with the highest number of COVID-19 cumulative cases and related cumulative deaths across the five regions of Africa as of 31 March 2021

\begin{tabular}{|l|r|r|r|}
\hline Countries & African Region & Cumulative Infection Cases & Cumulative Deaths \\
\hline Egypt & North & 201432 & 11956 \\
\hline Nigeria & West & 162762 & 2056 \\
\hline Ethiopia & East & 204521 & 2841 \\
\hline Cameroon & Central & 47669 & 721 \\
\hline South Africa & Southern & 1546735 & 52788 \\
\hline
\end{tabular}

Table 3: The new infection peaked values for the first five countries in each region of Africa 


\begin{tabular}{|c|c|c|c|c|c|c|c|c|}
\hline Country & $\begin{array}{l}\text { Africa } \\
\text { Region }\end{array}$ & $\begin{array}{c}\text { First } \\
\text { Reported } \\
\text { case }\end{array}$ & $\begin{array}{l}\text { Time } \\
\text { of } \\
\text { First } \\
\text { Peak }\end{array}$ & $\begin{array}{c}\text { Time } \\
\text { from } 1^{\text {st }} \\
\text { case till } \\
1^{\text {st }} \text { peak } \\
\text { in cases } \\
\text { (months) }\end{array}$ & $\begin{array}{l}\text { Number } \\
\text { of New } \\
\text { cases at } \\
1^{\text {st }} \text { Peak }\end{array}$ & $\begin{array}{c}\text { Time of } \\
\text { Second } \\
\text { Peak }\end{array}$ & $\begin{array}{c}\text { Time } \\
\text { between } \\
1^{\text {st }} \text { and } \\
2^{\text {nd }} \text { Peak } \\
\text { in cases } \\
\text { (months) }\end{array}$ & $\begin{array}{c}\text { Number } \\
\text { of New } \\
\text { cases at } \\
2^{\text {nd }} \\
\text { Peak }\end{array}$ \\
\hline Egypt & North & $\begin{array}{c}\text { Feb } \\
2020\end{array}$ & $\begin{array}{l}\text { June } \\
2020\end{array}$ & 4 & 43305 & $\begin{array}{c}\text { January } \\
2021\end{array}$ & 7 & 28774 \\
\hline Nigeria & West & $\begin{array}{l}\text { Feb } \\
2020\end{array}$ & $\begin{array}{l}\text { July } \\
2020\end{array}$ & 5 & 17556 & $\begin{array}{c}\text { January } \\
2021\end{array}$ & 6 & 43981 \\
\hline Ethiopia & East & $\begin{array}{l}\text { March } \\
2020\end{array}$ & $\begin{array}{c}\text { August } \\
2020\end{array}$ & 5 & 34507 & & & \\
\hline Cameroon & Central & $\begin{array}{l}\text { March } \\
2020\end{array}$ & $\begin{array}{l}\text { June } \\
2020\end{array}$ & 3 & 6933 & & & \\
\hline $\begin{array}{l}\text { South } \\
\text { Africa }\end{array}$ & Southern & $\begin{array}{l}\text { March } \\
2020\end{array}$ & $\begin{array}{l}\text { July } \\
2020\end{array}$ & 4 & 337905 & $\begin{array}{c}\text { January } \\
2021\end{array}$ & 6 & 410075 \\
\hline
\end{tabular}

Table 4: Deaths peaked values for the first five countries in each region of Africa 


\begin{tabular}{|c|c|c|c|c|c|c|c|c|}
\hline Country & $\begin{array}{l}\text { Africa } \\
\text { Region }\end{array}$ & $\begin{array}{l}\text { First } \\
\text { Reported } \\
\text { Death }\end{array}$ & $\begin{array}{l}\text { Time } \\
\text { of } \\
\text { First } \\
\text { Peak } \\
\text { in } \\
\text { Deaths }\end{array}$ & $\begin{array}{c}\text { Time } \\
\text { from } 1^{\text {st }} \\
\text { case till } \\
1^{\text {st }} \text { peak } \\
\text { in } \\
\text { deaths } \\
\text { (months) }\end{array}$ & $\begin{array}{l}\text { Number } \\
\text { of } \\
\text { Deaths } \\
\text { at } 1^{\text {st }} \\
\text { Peak }\end{array}$ & $\begin{array}{l}\text { Time of } \\
\text { Second } \\
\text { peak in } \\
\text { Deaths }\end{array}$ & $\begin{array}{l}\text { Time } \\
\text { between } \\
1^{\text {st }} \text { and } \\
2^{\text {nd }} \text { Peak } \\
\text { in } \\
\text { deaths } \\
\text { (months }\end{array}$ & $\begin{array}{l}\text { Number } \\
\text { of New } \\
\text { deaths } \\
\text { at } 2^{\text {nd }} \\
\text { Peak }\end{array}$ \\
\hline Egypt & North & $\begin{array}{l}\text { March } \\
2020\end{array}$ & $\begin{array}{l}\text { June } \\
2020\end{array}$ & 3 & 1959 & $\begin{array}{l}\text { January } \\
2021\end{array}$ & 7 & 28774 \\
\hline Nigeria & West & $\begin{array}{l}\text { March } \\
2020\end{array}$ & $\begin{array}{l}\text { July } \\
2020\end{array}$ & 4 & 305 & $\begin{array}{l}\text { February } \\
2021\end{array}$ & 7 & 327 \\
\hline Ethiopia & East & $\begin{array}{l}\text { April } \\
2020\end{array}$ & $\begin{array}{l}\text { August } \\
2020\end{array}$ & 4 & 530 & & & \\
\hline Cameroon & Central & $\begin{array}{l}\text { March } \\
2020\end{array}$ & $\begin{array}{l}\text { June } \\
2020\end{array}$ & 3 & 128 & & & \\
\hline $\begin{array}{l}\text { South } \\
\text { Africa }\end{array}$ & Southern & $\begin{array}{l}\text { March } \\
2020\end{array}$ & $\begin{array}{l}\text { August } \\
2020\end{array}$ & 5 & 6216 & $\begin{array}{l}\text { January } \\
2021\end{array}$ & 5 & 15918 \\
\hline
\end{tabular}

Figures 
A

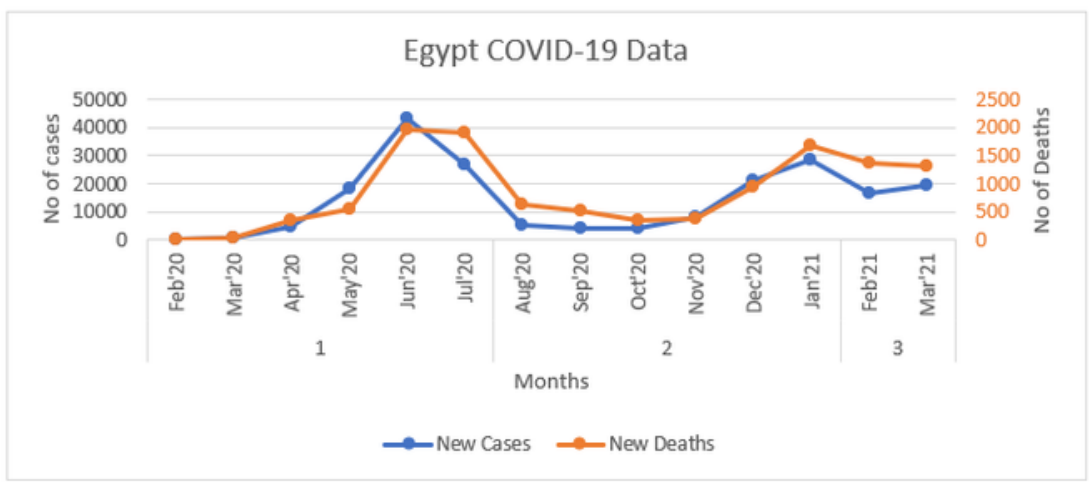

B

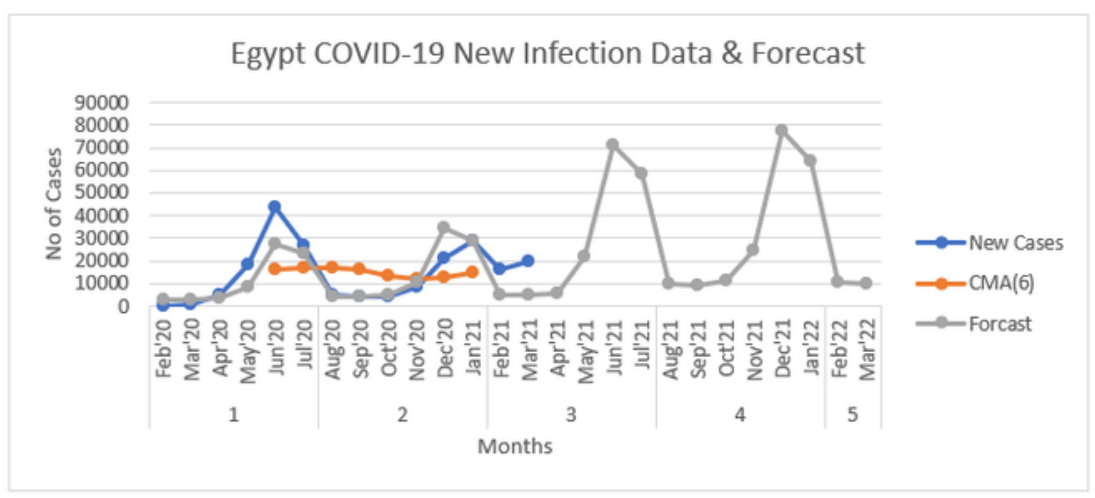

C

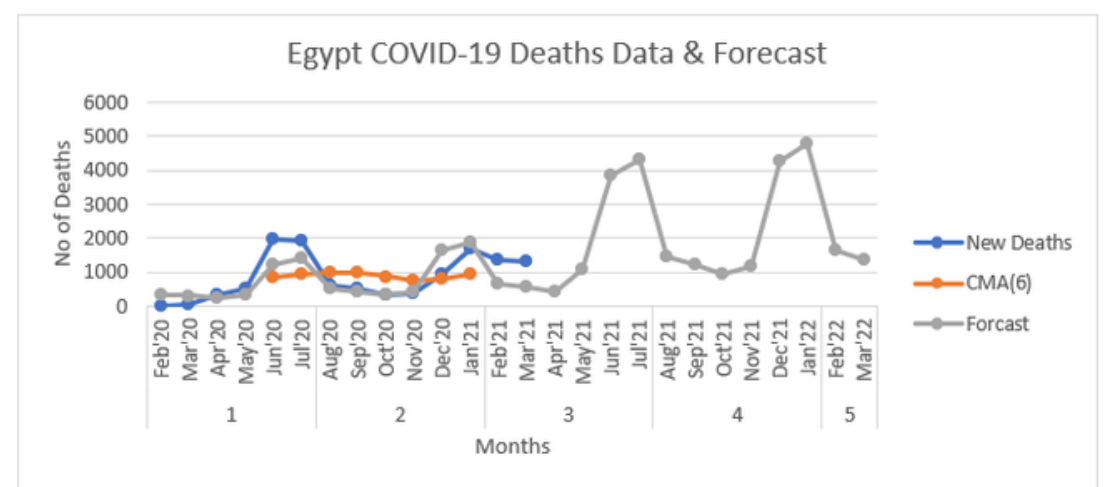

Figure 1

Illustration of findings for Egypt. A. Covid-19 cumulative infection cases and death cases, B. New infections data and forecast, C. New deaths data and forecast. 


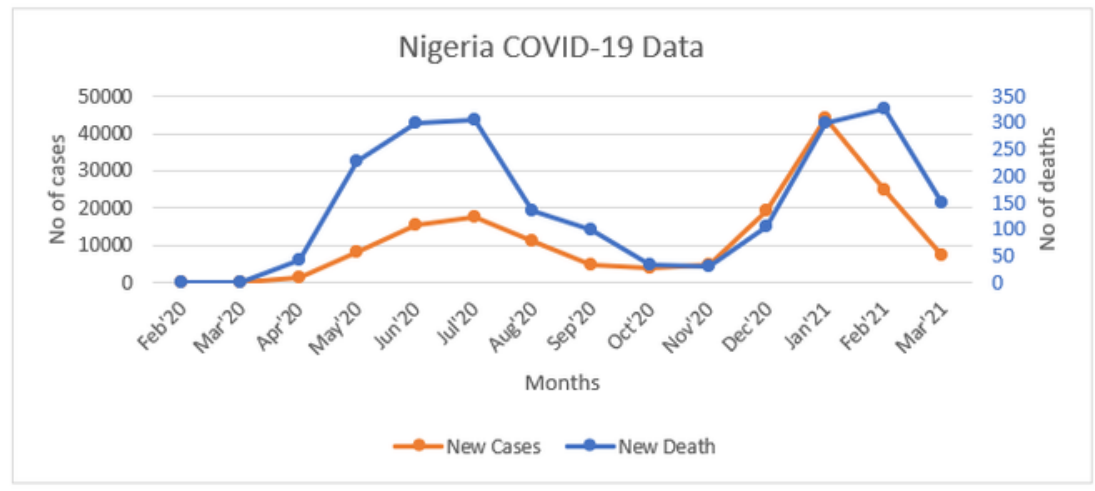

B

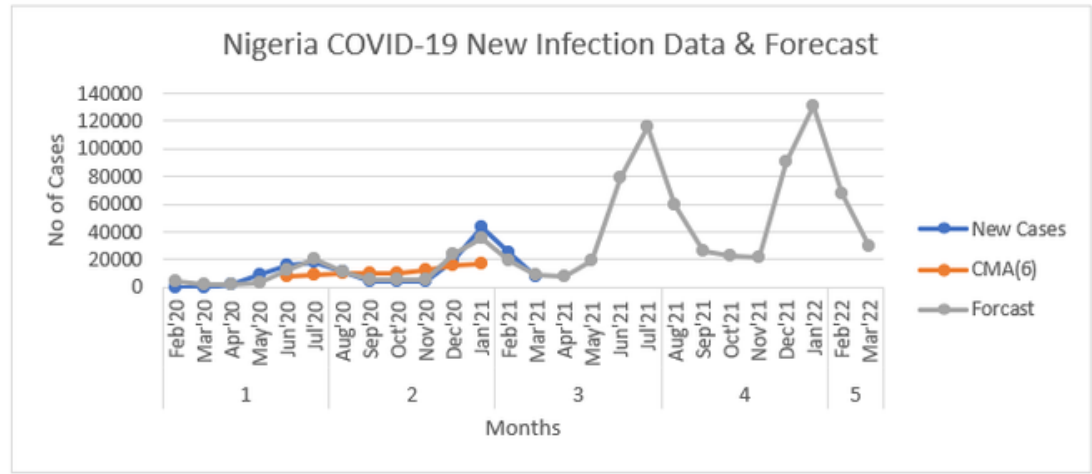

C

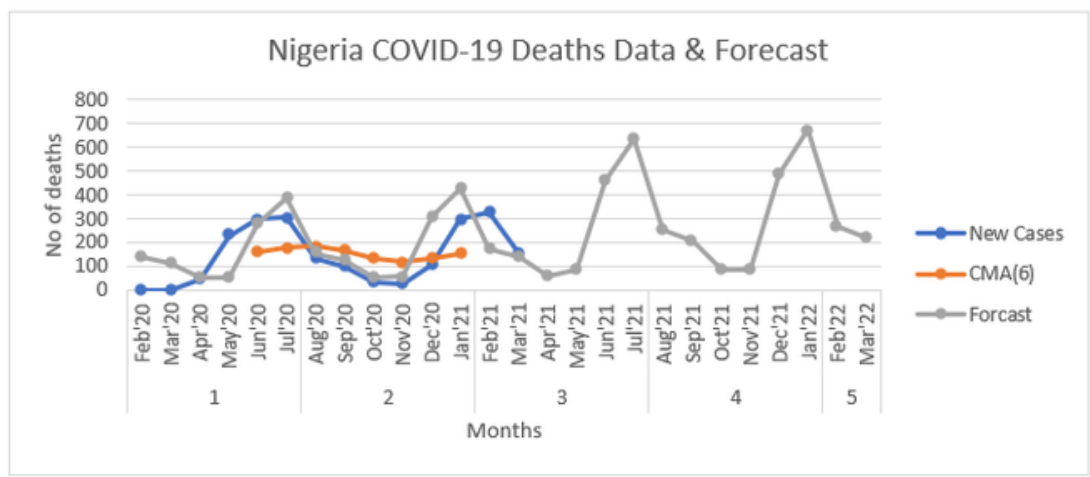

\section{Figure 2}

Illustration of findings for Nigeria. A. Covid-19 cumulative infection cases and death cases, B. New infections data and forecast, C. New deaths data and forecast 


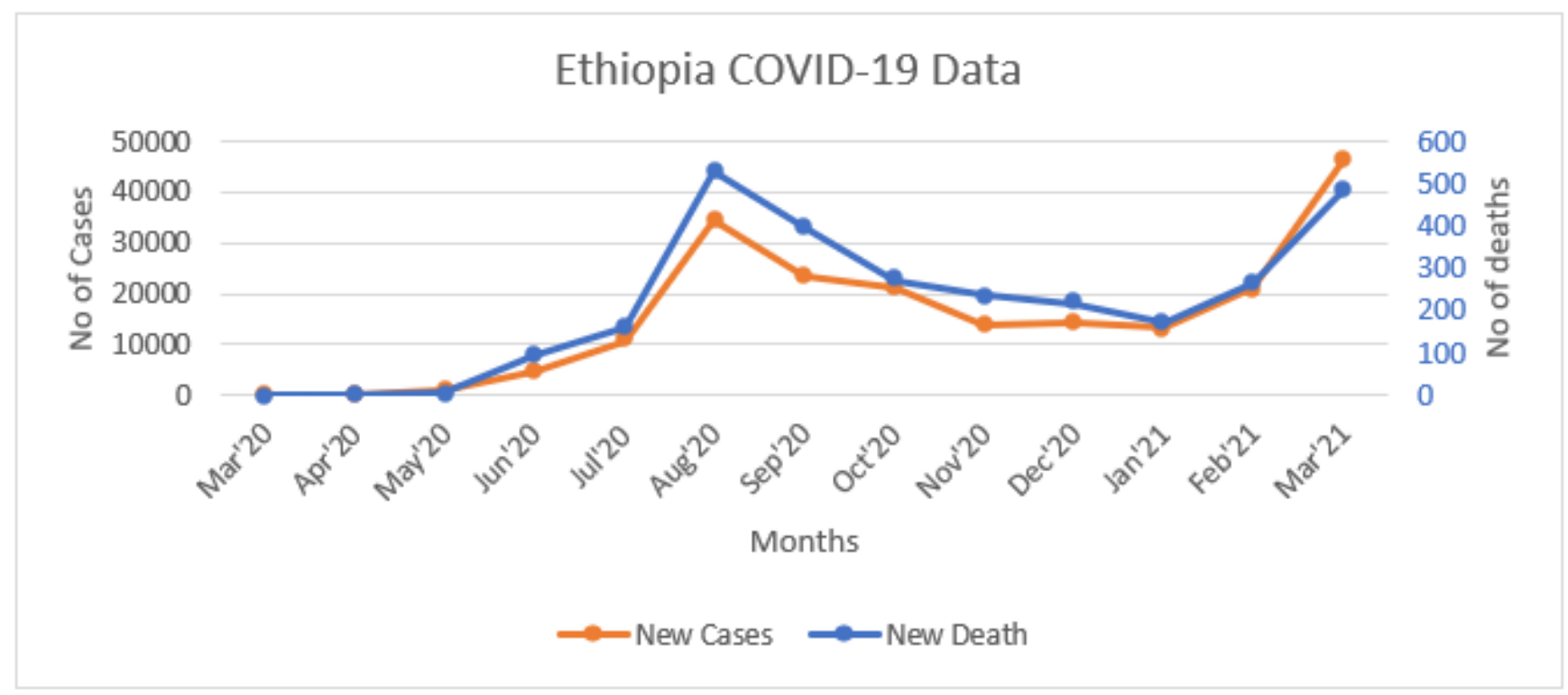

\section{Figure 3}

Illustration of findings for Covid-19 cumulative infection cases and death cases in Ethiopia. 
A

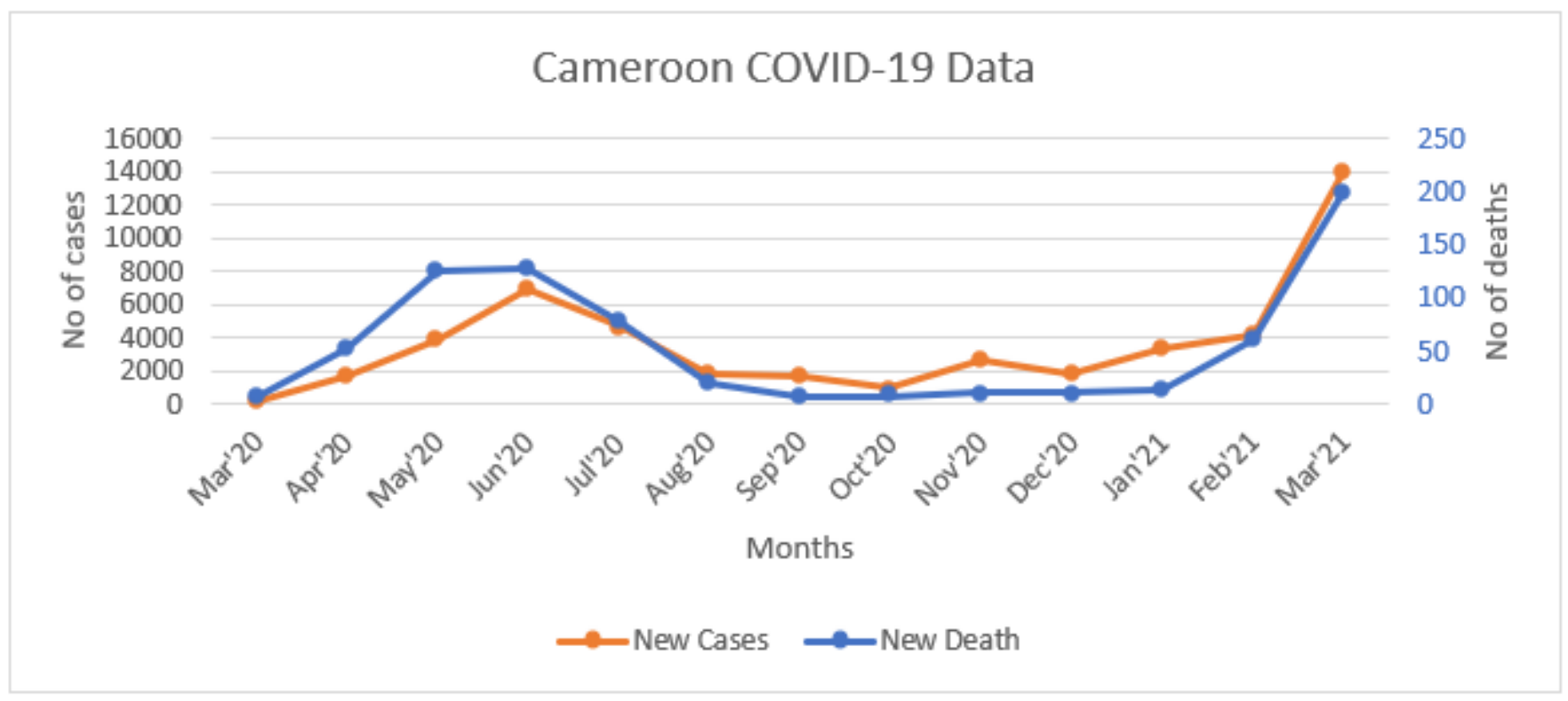

B

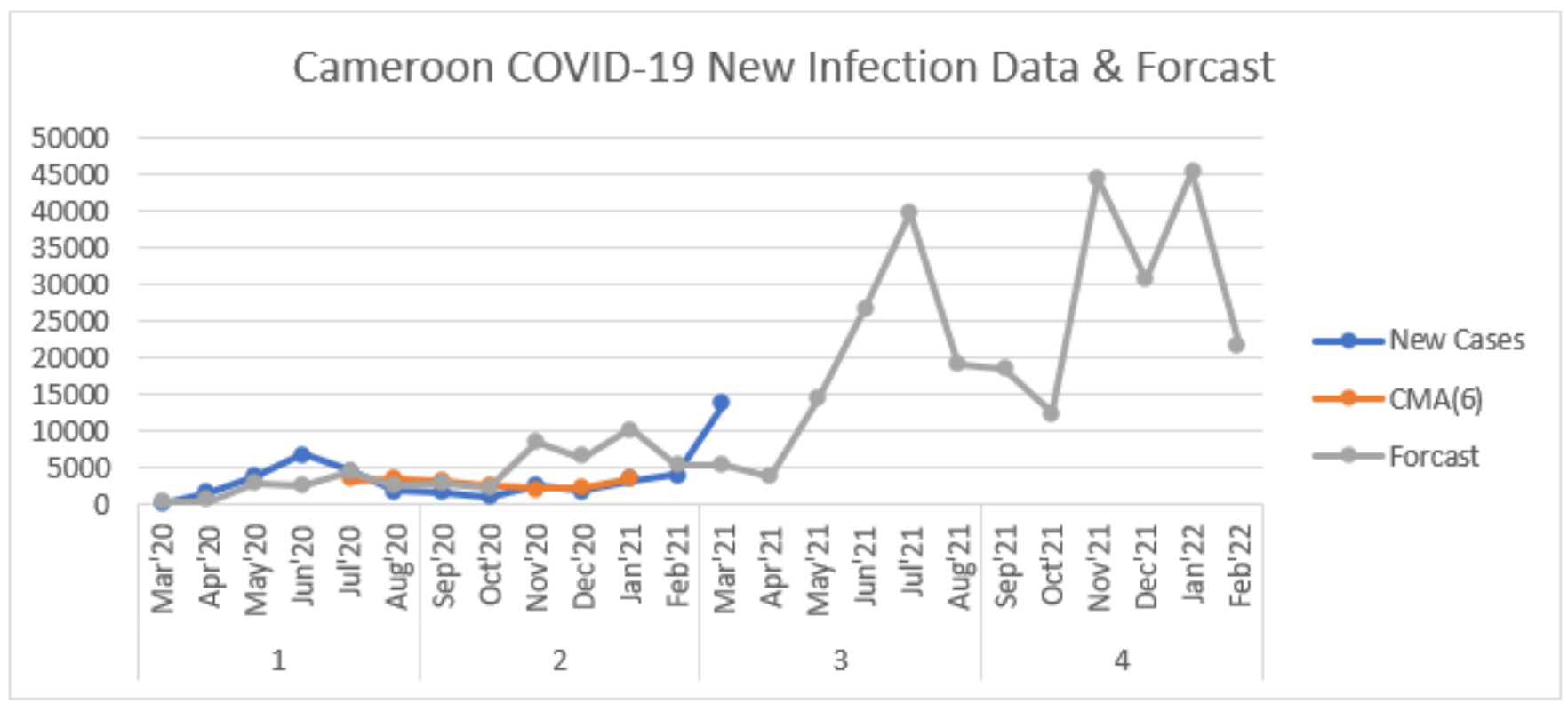

Figure 4

Illustration of findings for Cameroon. A. Covid-19 cumulative infection cases and death cases, B. Infection data and forecast. 


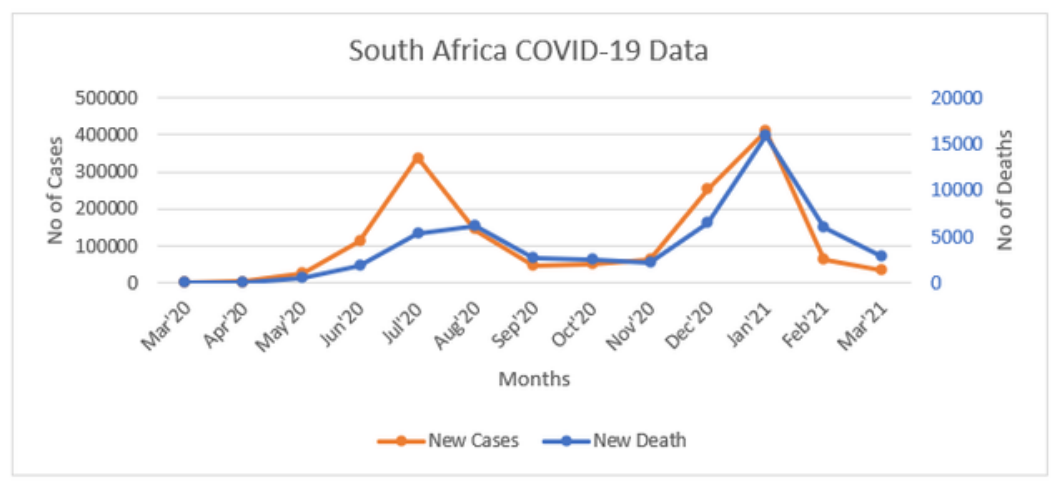

B

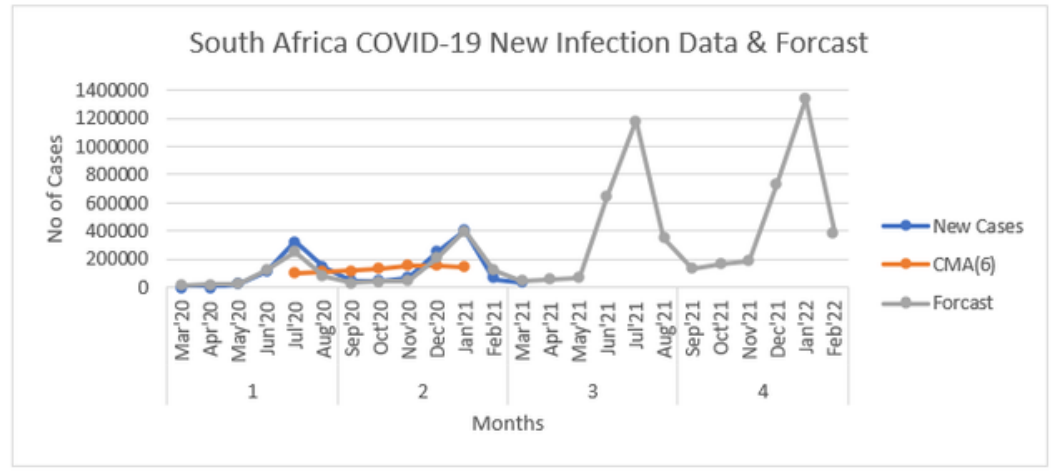

C

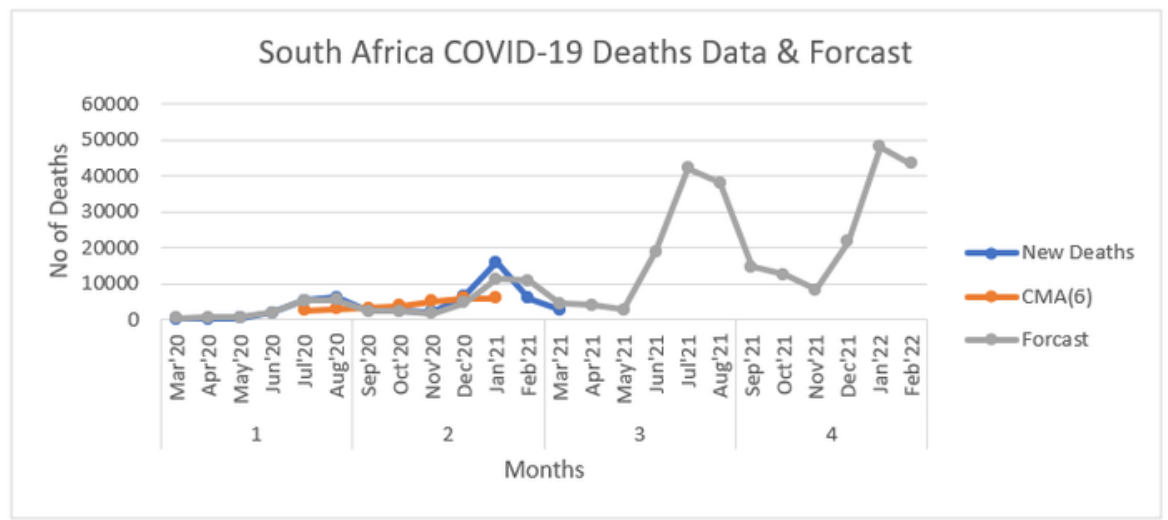

\section{Figure 5}

Illustration of findings for South Africa. A. Covid-19 cumulative infection cases and death cases, B. New infections data and forecast, $\mathrm{C}$. New deaths data and forecast 